\title{
Genome sequence of the anaerobic bacterium Bacillus $s p$. strain ZYK, a selenite and nitrate reducer from paddy soil
}

\author{
PengBao ${ }^{1}$, Jian-QiangSu ${ }^{2}$, Zheng-YiHu ${ }^{3}$, Max M.Häggblom ${ }^{4}$, Yong-GuanZhu ${ }^{1,2} *$ \\ ${ }^{1}$ State Key Lab of Urban and Regional Ecology, Research Center for Eco-Environmental \\ Sciences, Chinese Academy of Sciences, Beijing, P. R. China \\ ${ }^{2}$ Key Lab of Urban Environment and Health, Institute of Urban Environment, Chinese \\ Academy of Sciences, Xiamen, P. R. China \\ ${ }^{3}$ College of Resources and Environment, University of Chinese Academy of Sciences, \\ Beijing, China \\ ${ }^{4}$ Rutgers University, Department of Biochemistry and Microbiology, School of \\ Environmental and Biological Sciences, New Brunswick, NJ, USA
}

Correspondence: Yong-Guan Zhu (yg zhu@rcees.ac.cn)

Keywords: anaerobic, spore-forming, Gram-positive, nitrate-reduction, selenite-reduction, arsenic resistance, paddy soil, Bacillaceae

Bacillus sp. strain ZYK, a member of the phylum Firmicutes, is of interest for its ability to reduce
nitrate and selenite and for its resistance to arsenic under anaerobic conditions. Here we de-
scribe some key features of this organism, together with the complete genome sequence and
annotation. The 3,575,797 bp long chromosome with its 3,454 protein-coding and 70 RNA
genes, and the information gained from its sequence will be relevant to the elucidation of
microbially-mediated transformations of nitrogen, selenium and arsenic in paddy soil.

\section{Introduction}

Bacillus sp. ZYK (=DSM 26460 =CGMCC 1.5179) was isolated from a paddy soil in Dehong, Yunnan, China and is an anaerobic nitrate-reducing, Grampositive bacterium [1]. Strain ZYK belongs to the genus Bacillus, and based on 16S rRNA phylogeny, is most closely related to Bacillus azotoformans isolated from garden soil, which is capable of reducing nitrate, nitrite, nitrous oxide, and nitric oxide under anaerobic conditions [2-4]. Strain ZYK is capable of nitrate-reduction under anaerobic conditions and, in addition, demonstrated selenite-reducing ability and arsenic resistance (unpublished data). Bacillus spp. are commonly found in paddy soil and may play important roles in elemental cycling during periodically changing redox conditions [5-8]. Therefore, strain ZYK is a suitable model for studying the properties of genes involved in denitrification, selenitereduction and arsenic resistance pathways of paddy soil bacteria. Here we summarize the features of Bacillus sp. strain ZYK and provide a description of its sequenced genome, now available for detailed analysis.

\section{Classification and features}

Based on 16S rRNA gene phylogeny and genome information, strain ZYK was a member of the genus Bacillus, most closely related to Bacillus azotoformans (AB363732), with a sequence similarity of $96.3 \%$ based on a Blast analysis [9] of the most recent release of the Greengenes database [10]. A phylogenetic tree (Figure 1) was constructed using the Maximum likelihood method under the default settings for complete sequences of genes encoding 16S rRNA derived from sequenced genomes of Bacillus spp., along with the sequences of representative members of the genus.

Strain ZYK is an anaerobic, Gram-positive, sporeforming, motile, rod-shaped $(0.2-0.3 \mu \mathrm{m}$ wide and 1.5-2.0 $\mu \mathrm{m}$ long) (Figure 2). The strain grew optimally at $\mathrm{pH} 7.0-7.2$ (range $6.0-7.6$ ), $30-40^{\circ} \mathrm{C}$ (range $21-45^{\circ} \mathrm{C}$ ) and at low salinity ( $\mathrm{NaCl}$ range $0-1.1 \%$ ) (Table 1) in freshwater anaerobic medium [24]. On anaerobic LB agar, strain ZYK forms small, white colonies with entire edges (data not shown). Carbon substrates utilized for growth by strain ZYK included D-glucose, maltose, lactose, and sucrose. Strain ZYK reduces nitrate and selenite under anaerobic conditions in freshwater medium. 


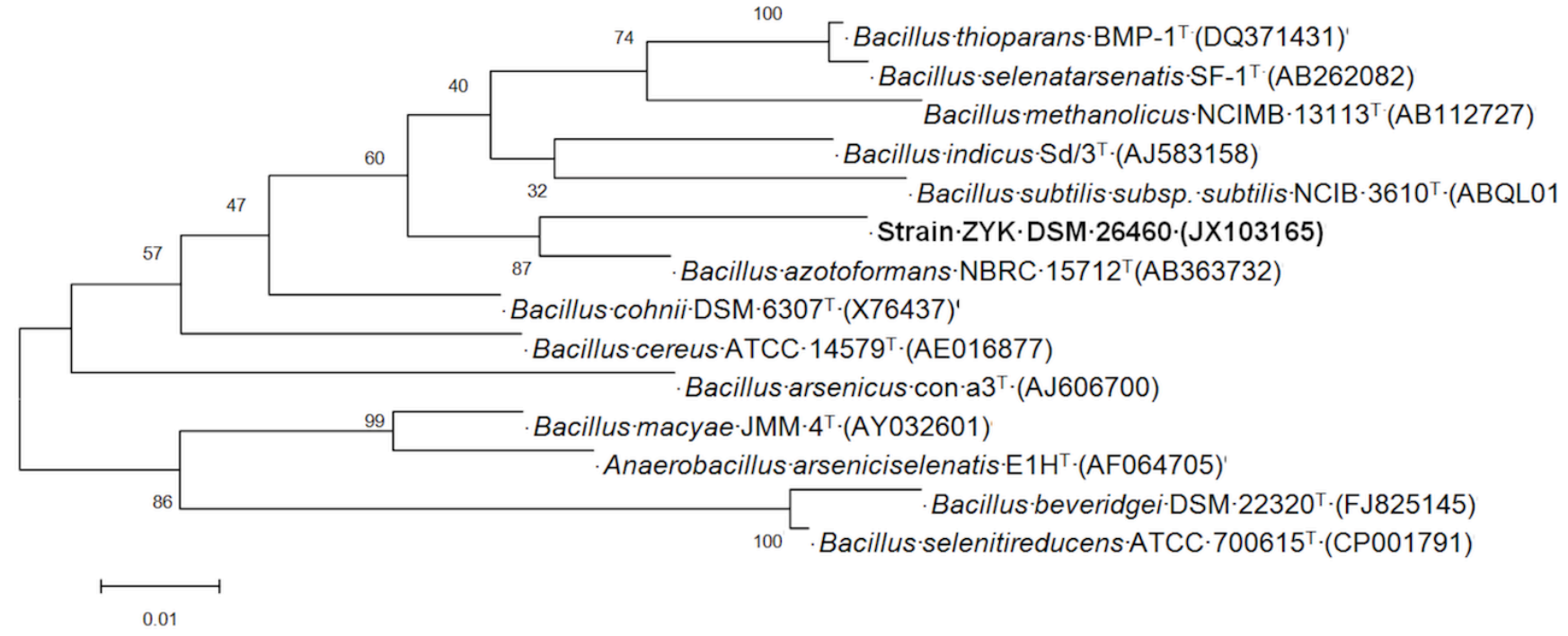

Figure 1. Phylogenetic tree highlighting the position of Bacillus sp. ZYK relative to selected Bacillus species. The strains and their corresponding GenBank accession numbers of $16 \mathrm{~S}$ rRNA genes are as indicated. The tree, based on 1,545 positions, was built with MEGA 5 [11] using the Maximum likelihood method. Bar: 0.01substitutions per nucleotide position.

Table 1. Classification and general features of strain ZYK according to the MIGS recommendations [1]

\begin{tabular}{|c|c|c|c|}
\hline MIGS ID & Property & Term & Evidence codes \\
\hline & \multirow{7}{*}{ Classification } & Domain Bacteria & TAS [12] \\
\hline & & Phylum Firmicutes & TAS [13-15] \\
\hline & & Class Bacilli & TAS $[16,17]$ \\
\hline & & Order Bacillales & TAS $[18,19]$ \\
\hline & & Family Bacillaceae & TAS $[18,20]$ \\
\hline & & Genus Bacillus & TAS $[18,21,22]$ \\
\hline & & Strain ZYK & IDA \\
\hline & Gram stain & Positive & IDA \\
\hline MIGS-37.1 & Cell shape & Rod-shaped & NAS \\
\hline MIGS-37.2 & Motility & Motile & NAS \\
\hline MIGS-37.3 & Sporulation & Sporulating & NAS \\
\hline MIGS-37.9 & Cell arrang ement & Sing le & NAS \\
\hline MIGS-37.12 & Optimum pH & 7.0 & NAS \\
\hline \multirow[t]{2}{*}{ MIGS-6 } & Optimum temperature & $30^{\circ} \mathrm{C}$ & NAS \\
\hline & Salinity & $0-1.1 \%$ & IDA \\
\hline \multirow[t]{2}{*}{ MIGS-22 } & Oxygen requirement & Strict & NAS \\
\hline & Carbon source & D-Glucose, Maltose, lactose, sucrose & IDA \\
\hline MIGS-6 & Habitat & Paddy soil & NAS \\
\hline \multirow[t]{3}{*}{ MIGS-15 } & Biotic relationship & Free-living & NAS \\
\hline & Pathog enicity & None-pathog en & NAS \\
\hline & Biosafety level & 1 & NAS \\
\hline MIGS-4 & Geographic location & Dehong, Yunnan, China & NAS \\
\hline MIGS-4.1 & Latitude & $24^{\circ} 64^{\prime} 70^{\prime \prime} \mathrm{N}$ & NAS \\
\hline MIGS-4.2 & Long itude & $98^{\circ} 53^{\prime} 45^{\prime \prime} \mathrm{E}$ & NAS \\
\hline MIGS-4.5 & Isolation & Paddy soil & NAS \\
\hline
\end{tabular}

Evidence codes - IDA: Inferred from Direct Assay; TAS: Traceable Author Statement (i.e., a direct report exists in the literature); NAS: Non-traceable Author Statement (i.e., not directly observed for the living, isolated sample, but based on a generally accepted property for the species, or anecdotal evidence). These evidence codes are from the Gene Ontology project [23]. If the evidence code is IDA, the property was directly observed by one of the authors. 


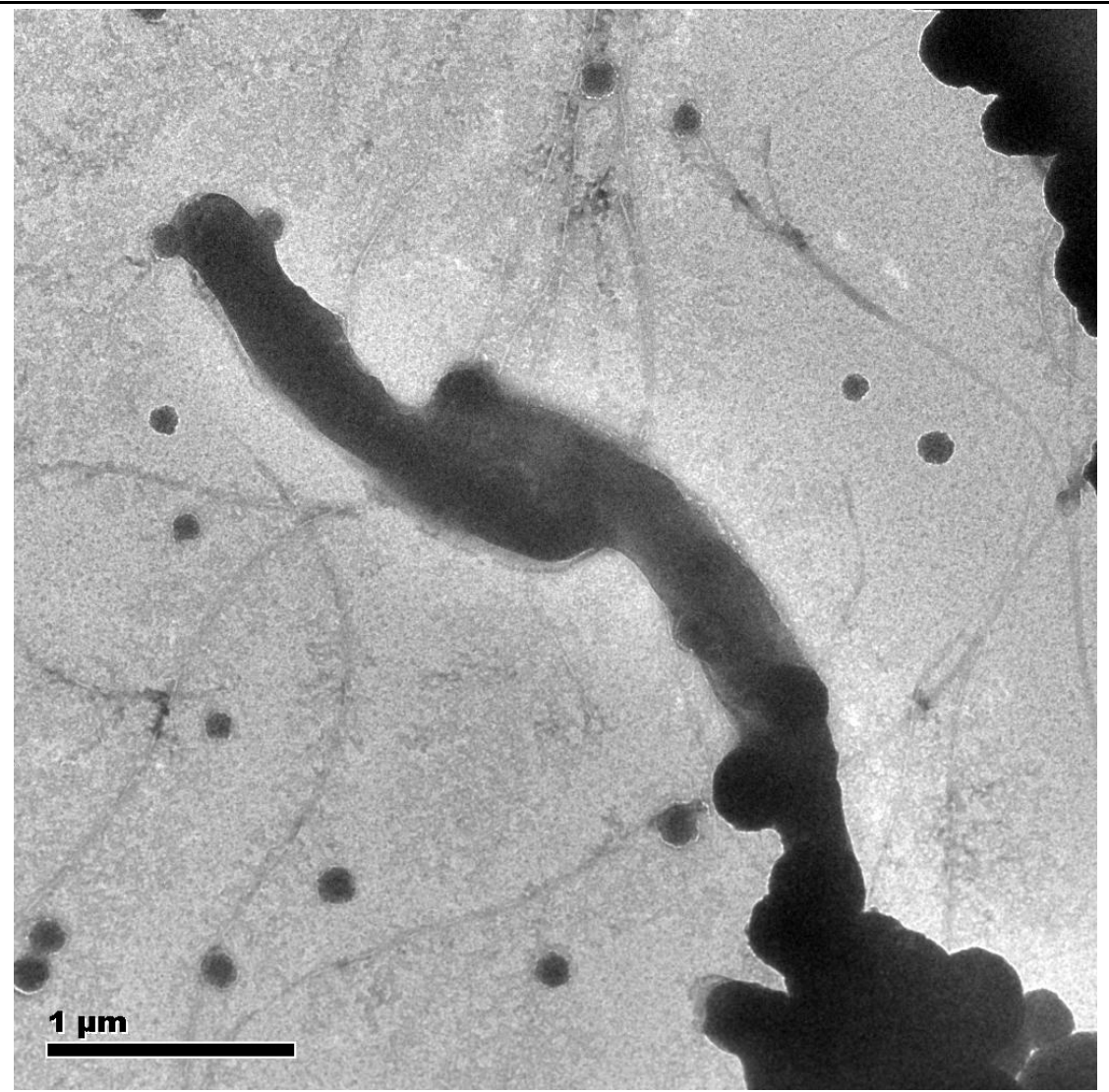

Figure 2. Transmission electron microscopy of strain ZYK. Scale bar corresponds to $1.0 \mathrm{pn}$.

\section{Genome project history}

Bacillus sp. ZYK was selected for sequencing because of its phylogenetic affiliation with a lineage of paddy soil bacteria that may influence elemental cycling in paddy fields. The genome project is deposited in the Genomes OnLine Database (GOLD) as project Gi22906, and the complete genome sequence is in GenBank under accession number ANOK00000000 (Table 2). A summary of the main project information is shown in Table 2.

\section{Growth conditions and DNA isolation}

For the preparation of genomic DNA, one colony was picked from an anaerobic LB agar plate, and grown in anaerobic freshwater medium at $30^{\circ} \mathrm{C}$ [24]. A culture $(1.0 \mathrm{ml})$ at $0.6 \mathrm{OD}_{600 \mathrm{~nm}}$ was inoculated into $100 \mathrm{ml}$ of anaerobic freshwater media. Cells were collected by centrifugation after growing to $0.6 \mathrm{OD}_{600 \mathrm{~nm}}$. Cells were suspended in TE buffer $(10 \mathrm{mM} \mathrm{NaCl}, 20 \mathrm{mM}$ Tris- $\mathrm{HCl}, 1.0 \mathrm{mM}$ EDTA, pH 8.0), and treated with lysozyme to lyse the cell wall. SDS and proteinaseK were added to denature and degrade proteins. Cell lysates were extracted with phenol-chloroform and the nucleic acids were precipitated by addition of isoamylol.
The nucleic acid pellet was washed with $100 \%$ ethanol, dissolved in double distilled water and then treated with RNase A [25].

\section{Genome sequencing and assembly}

The genome of ZYK was sequenced at the Beijing Genomics Institute (BGI) using Illumina pairedend sequencing. Draft assemblies were based on $4,233,334$ reads totaling $380 \mathrm{Mb}$ of $500 \mathrm{bp}$ PCRfree library and 2,184,080 reads totaling $196 \mathrm{Mb}$ of 2,000 bp index library. The SOAPdenovo software package independently developed by BGI (version 1.05 [26],) was used for sequence assembly and quality assessment. To achieve optimal assembly results, the key parameter $\mathrm{K}$ was set at 43 after several adjustments. Gaps between contigs were closed by KRSKGF software, version 1.2 (independently developed by BGI) and Gapcloser, version 1.10. The complete nucleotide sequence of Bacillus sp. strain ZYK and its annotation can be found online at the IMG (Integrated Microbial Genome) portal of JGI [27], as well at the genome resource site of NCBI [28]. 
Table 2. Genome sequencing project information

\begin{tabular}{lll}
\hline MIGS ID & Property & Term \\
\hline MIGS-31 & Finishing quality & Complete \\
MIGS-28 & Libraries used & Two libraries 500 bp PCR-free library, 2000 bp index library \\
MIGS-31.2 & Fold coverage & Illumina \\
MIGS-30 & Assemblers & 140× \\
MIGS-32 & Gene calling method & SOAPdenovo 1.05 \\
& Locus TAG & D612 \\
& Genbank ID & ANOK00000000 \\
& Genbank Date of Release & January 15, 2013 \\
& GOLD ID & Gi22906 \\
& NCBI taxon ID & 1191699 \\
MIGS-13 & Source material identifier & DSMZ 26460, CGMCC 1.5179 \\
MIGS-38.2 & Project relevance & Agricultural, Bioremediation, Environmental \\
\hline
\end{tabular}

\section{Genome annotation}

Genes were identified using Glimmer, version 3.0 [29]. The predicted CDSs were translated and used to search KEGG, COG, SwissPort, TrEMBL, NR and GO databases. These data sources were combined to assert a product description for each predicted protein. Transposons were identified using RepeatMaster (with Repbase) and RepeatProteinMasker (with its own database) software. Tandem repeat sequences were predicted by TRF (Tandem Repeat Finder) software. The rRNA, tRNA and sRNA were predicted by using rRNAmmer [30], tRNAscan [31] and Rfam [32] software, respectively.

\section{Genome properties}

The genome consists of a circular chromosome of $3,575,797$ bp in size with a GC content of $36.1 \%$ (Figure 3, Table 3). Of the 3,454 predicted genes, 70 are RNA genes, 136 are secreted protein coding genes, and 3,318 are non-secreted protein coding genes. Of the total predicted genes, 2,030 represent COG functional categories. The distribution of genes into COG functional categories is presented in Figure 3 and Table 4.

Table 3. Genome statistics

\begin{tabular}{lrr}
\hline Attribute & Value & \% of total \\
\hline Genome size (bp) & $3,575,797$ & 100.00 \\
DNA coding reg ion (bp) & $3,002,982$ & 83.98 \\
DNA G+C content (bp) & $1,290,862$ & 36.10 \\
Total genes & 3454 & 100.00 \\
RNA genes & 70 & 2.03 \\
Protein-coding genes (bp) & $3,002,982$ & 83.98 \\
Genes with function prediction & 3261 & 94.41 \\
Genes assigned to COGs & 2,030 & 58.77 \\
Genes assig ned to Pfam domains (bp) & 617,696 & 17.27 \\
Genes with signal peptides & 169 & 4.89 \\
Genes with transmembrane helices & 132 & 3.82 \\
CRISPR repeats & 84 & 0.09 \\
\hline
\end{tabular}


Table 4. Number of genes associated with the 25 general COG functional categ ories

\begin{tabular}{|c|c|c|c|}
\hline Code & Value & $\%$ age $^{a}$ & Description \\
\hline$J$ & 149.0 & 6.5 & Translation \\
\hline A & 0.0 & 0.0 & RNA processing and modification \\
\hline K & 164.0 & 7.1 & Transcription \\
\hline $\mathrm{L}$ & 119.0 & 5.2 & Replication, recombination and repair \\
\hline B & 1.0 & 0.04 & Chromatin structure and dynamics \\
\hline $\mathrm{D}$ & 27.0 & 1.2 & Cell cycle control, mitosis and meiosis \\
\hline Y & 0.0 & 0.0 & Nuclear structure \\
\hline V & 24.0 & 1.0 & Defense mechanisms \\
\hline $\mathrm{T}$ & 162.0 & 7.0 & Signal transduction mechanisms \\
\hline M & 95.0 & 4.1 & Cell wall/membrane biog enesis \\
\hline $\mathrm{N}$ & 75.0 & 3.3 & Cell motility \\
\hline Z & 0.0 & 0.0 & Cytoskeleton \\
\hline W & 0.0 & 0.0 & Extracellular structures \\
\hline$U$ & 44.0 & 1.9 & Intracellular trafficking and secretion \\
\hline $\mathrm{O}$ & 97.0 & 4.2 & Posttranslational modification, protein turnover, chaperones \\
\hline $\mathrm{C}$ & 155 & 6.7 & Energy production and conversion \\
\hline G & 79.0 & 3.4 & Carbohydrate transport and metabolism \\
\hline $\mathrm{E}$ & 239.0 & 10.4 & Amino acid transport and metabolism \\
\hline $\mathrm{F}$ & 61.0 & 2.7 & Nucleotide transport and metabolism \\
\hline $\mathrm{H}$ & 93.0 & 4.0 & Coenzyme transport and metabolism \\
\hline I & 97.0 & 4.2 & Lipid transport and metabolism \\
\hline $\mathrm{P}$ & 127.0 & 5.5 & Inorganic ion transport and metabolism \\
\hline Q & 38.0 & 1.7 & Secondary metabolites biosynthesis, transport and catabolism \\
\hline $\mathrm{R}$ & 261.0 & 11.3 & General function prediction only \\
\hline S & 193.0 & 8.4 & Function unknown \\
\hline - & 1424 & 41.2 & Not in COGs \\
\hline
\end{tabular}

a) The total is based on the total number of protein coding genes in the annotated genome. 


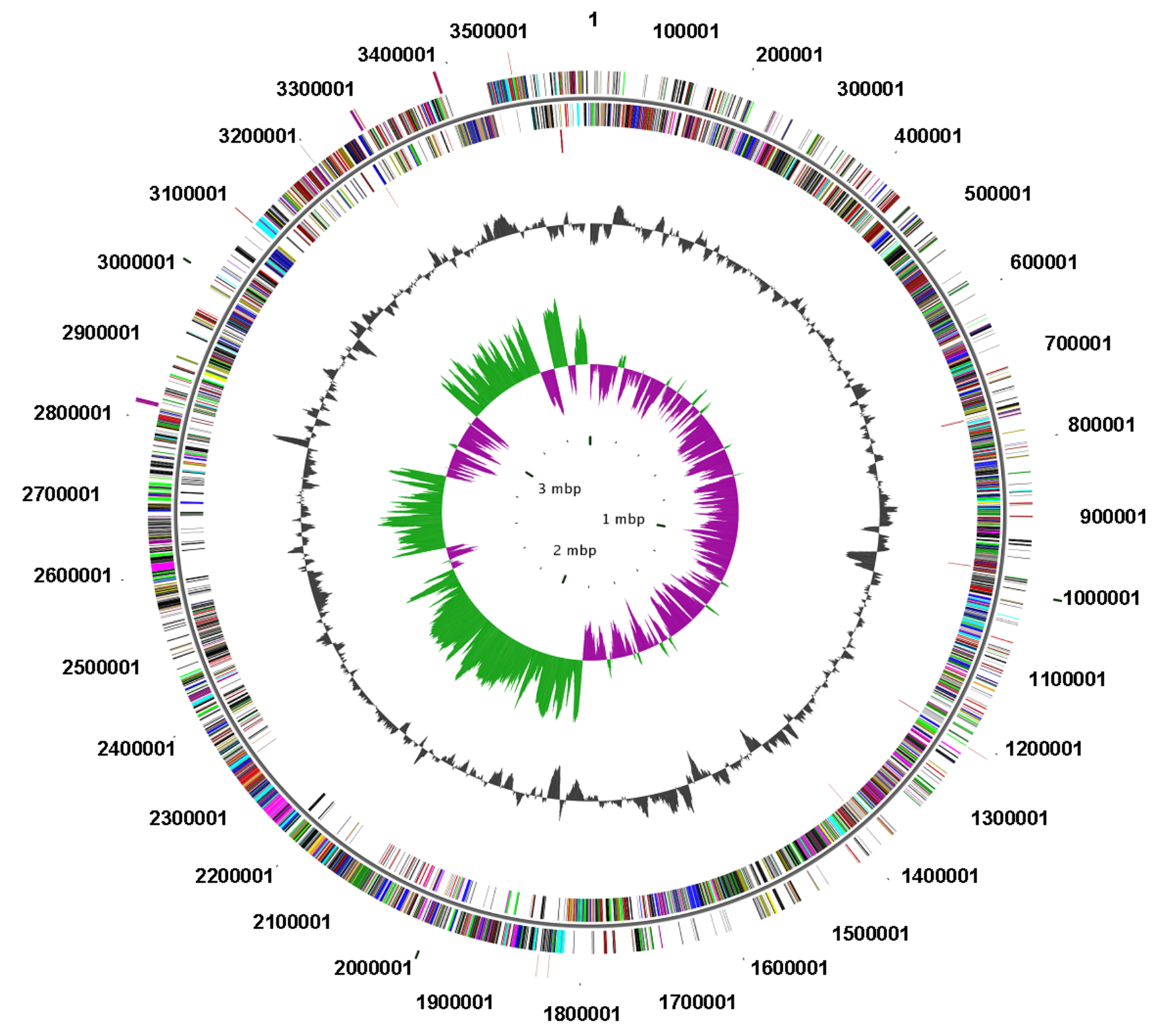

Figure 3. Graphical representation of circular map of the chromosome of strain ZYK. From outside to the center: Genes on forward strand (colored by COG categories), Genes on reverse strand (colored by COG categories), RNA genes (tRNAs green, rRNAs red, other RNAs black), GC content, GC skew.

\section{Insights into the genome sequence}

Bacillus sp. ZYK can reduce nitrate and selenite under anaerobic conditions (unpublished data). The inspection of the genome of strain ZYK confirmed the presence of nitrate reductase coding genes, in support of the physiological data. Genes for a respiratory nitrate reductase corresponding to a heterotrimeric structure with four subunits, including narG, narH, narI and narJ present in the genome of strain ZYK. Genes encoding a second type of nitrate reductase, Nap (periplasmic nitrate reductase) including $\operatorname{nap} A, \operatorname{napB}$, and napD were also found in the ZYK genome. We also identified in the genome a formate-dependent nitrite reductase coding gene (nrfA) and a coppercontaining nitrite reductase coding gene (nirK).

An arsenate reductase coding gene ( $\operatorname{ars} C$ ) was identified with $77 \%$ similarity to the Bacillus megaterium arsC gene (AJ515540). An arsenite efflux pump gene was also identified as ars $B$ with $78 \%$ similarity to Bacillus sp. CDB3 arsB gene (AF178758.2). Two DMSO reductase genes have $59.2 \%$ and $60.3 \%$ similarity with Desulfosporosinus orientis DMSO reductase (Fe-S cluster containing hydrogenase coding gene) and 
Bacillus sp. 1NLA3E DMSO reductase (dimethylsulfoxide reductase, chain $\mathrm{B}$ ), respectively. The discovery of an arsenate reductase coding gene $(\operatorname{ars} C)$ and DMSO reductase sequences suggests that the reduction capabilities of strain ZYK are broader than expected, and that other substrates be tested. Particularly, we are interested in determining whether selenite reduction activity in ZYK is mediated by a hydrogenase [33], a nitrite reductase [34] or a DMSO reductase. While the reduction of selenite to elemental selenium is a common feature of diverse microorganisms, the genes responsible for this process remain largely uncharacterized and virtually nothing is known about their regulation [33-35], or their interac-

\section{Acknowledgements}

We gratefully acknowledge the technically support of Beijing Genomics Institute (BGI), which worked on sequencing and annotation of this genome. This work

\section{References}

1. Field D, Garrity G, Gray T, Morrison N, Seleng ut J, Sterk P, Tatusova T, Thomson N, Allen MJ, Angiuoli SV, et al. The minimum information about a genome sequence (MIGS) specification. Nat Biotechnol 2008; 26:541-547. PubMed http://dx.doi.org/10.1038/nbt1360

2. Pichinoty F, Durand M, Job C, Mandel M, Garcia JL. Etude morphologique, physiologique et taxonomique de Bacillus azotoformans. Can J Microbiol 1978; 24:608-617. PubMed http://dx.doi.org/10.1139/m78-099

3. Pichinoty F, De Barjac H, Mandel M, Asselineau J. Description of Bacillus azotoformans. Int J Syst Bacteriol 1983; 33:660-662. http://dx.doi.org/10.1099/00207713-33-3-660

4. Suharti J, Heering HA, De Vries S. NO Reductase from Bacillus azotoformans Is a Bifunctional Enzyme Accepting Electrons from Menaquinol and a Specific Endogenous Membrane-Bound Cytochrome $C_{551}$. Biochem istry 2004; 43:1348713495. PubMed http://dx.doi.org/10.1021/bi0488101

5. Watanabe K, Hayano K. Distribution and identification of proteolytic Bacillus spp. in paddy field soil under rice cultivation. Can J Microbiol 1993; 39:674-680. PubMed http://dx.doi.org/10.1139/m93-097

6. Wang XJ, Yang J, Chen XP, Sun GX, Zhu YG. Phylogenetic diversity of dissimilatory ferric iron re- tions with other respiratory pathways. In addition to Bacillus sp. ZYK, the genomes of two bacteria capable of selenite reduction, Bacillus selenitireducens (NC_014219.1) [36] and Desulfirispirillum indicum S5 [37,38], have been sequenced. The investigation of the functional genes of strain ZYK will consequently enhance the understanding of the electron acceptor utilization pathways in microorganisms, and how nitrogen, selenium and arsenic cycling is mediated by microorganisms active in paddy soil. Further study of these reductase gene-coding sequences may reveal the importance of the Bacillus genus in elemental cycling in paddy soils.

was financially supported by the National Natural Science Foundation of China (No. 41090280) and (No. 41090282).

ducers in paddy soil of Hunan, South China. J Soils Sediments 2009; 9:568-577. http://dx.doi.org/10.1007/s11368-009-0113-x

7. Li H, Peng JJ, Weber KA, Zhu YG. Phylog enetic diversity of $\mathrm{Fe}(\mathrm{III})$-reducing microorganisms in rice paddy soil: enrichment cultures with different short-chain fatty acids as electron donors. J Soils Sediments 2011; 11:12 34-1242. http://dx.doi.org/10.1007/s11368-011-0371-2

8. Kögel-Knabner I, Amelung W, Cao Z, Fiedler S, Frenzel P, Jahn R, Kalbitz K, Kölbl A, Schloter M. Biogeochemistry of paddy soils. Geoderma 2010; 157:1-14.

http://dx.doi.org/10.1016/j.geoderma.2010.03.00 $\underline{9}$

9. Altschul SF, Gish W, Miller W, Myers EW, Lipman DJ. Basic local alignment search tool. J Mol Biol 1990; 215:403-410. PubMed

10. DeSantis TZ, Hugenholtz $\mathrm{P}$, Larsen N, Rojas M, Brodie EL, Keller K, Huber T, Dalevi D, Hu P, Andersen GL. Greengenes, a Chimera-Checked 16S rRNA Gene Database and Workbench Compatible with ARB. Appl Environ Microbiol 2006; 72:5069-5072. PubMed http://dx.doi.org/10.1128/AEM.03006-05

11. Tamura K, Peterson D, Peterson N, Stecher G, Nei M, Kumar S. MEGA5: Molecular Evolutionary Genetics Analysis using Maximum Likelihood, Evolutionary Distance, and Maximum Parsimony 
Methods. Mol Biol Evol 2011; 28:2731-2739.

PubMed

http://dx.doi.org/10.1093/molbev/msr121

12. Woese CR, Kandler O, Wheelis ML. Towards a natural system of org anisms: proposal for the domains Archaea, Bacteria, and Eucarya. Proc Natl Acad Sci USA 1990; 87:4576-4579. PubMed http://dx.doi.org/10.1073/pnas.87.12.4576

13. Gibbons NE, Murray RGE. Proposals Concerning the Higher Taxa of Bacteria. Int J Syst Bacteriol 1978; 28:1-6. http://dx.doi.org/10.1099/00207713-28-1-1

14. Garrity GM, Holt JG. The Road Map to the Manual. In: Garrity GM, Boone DR, Castenholz RW (eds), Bergey's Manual of Systematic Bacteriology, Second Edition, Volume 1, Springer, New York, 2001, p. 119-169.

15. Murray RGE. The Higher Taxa, or, a Place for Everything...? In: Holt JG (ed), Bergey's Manual of Systematic Bacteriology, First Edition, Volume 1, The Williams and Wilkins Co., Baltimore, 1984, p. 31-34.

16. List no. 132. List of new names and new combinations previously effectively, but not validly, published. Int J Syst Evol Microbiol 2010; 60:469472. http://dx.doi.org/10.1099/ijs.0.022855-0

17. Ludwig W, Schleifer KH, Whitman WB. Class I. Bacilli class nov. In: De Vos P, Garrity G, Jones D, Krieg NR, Ludwig W, Rainey FA, Schleifer KH, Whitman WB (eds), Bergey's Manual of Systematic Bacteriology, Second Edition, Volume 3, Spring er-Verlag, New York, 2009, p. 19-20.

18. Skerman VBD. McGowanV, SneathPHA. Approved Lists of Bacterial Names. Int J Syst Bacteriol 1980; 30:225-420. http://dx.doi.org/10.1099/00207713-30-1-225

19. Prévot AR. In: Hauderoy P, Ehring er G, Guillot G, Magrou. J., Prévot AR, Rosset D, Urbain A (eds), Dictionnaire des Bactéries Pathogènes, Second Edition, Masson et Cie, Paris, 1953, p. 1-692.

20. Fischer A. Untersuchung en über bakterien. Jahrbücher für Wis senschaftliche Botanik 1895; 27:1-163.

21. Cohn F. Untersuchungen über Bakterien. Beitr Biol Pflanz 1872; 1:127-224.

22. Gibson T, Gordon RE. Genus I. Bacillus Cohn 1872, 174; Nom. gen. cons. Nomencl. Comm. Intern. Soc. Microbiol. 1937, 28; Opin. A. Jud. Comm. 1955, 39. In: Buchanan RE, Gibbons NE (eds), Bergey's Manual of Determinative Bacteri- ology, Eighth Edition, The Williams and Wilkins Co., Baltimore, 1974, p. 529-550.

23. Ashburner M, Ball CA, Blake JA, Botstein D, Butler $\mathrm{H}$, Cherry JM, Davis AP, Dolinski K, Dwight SS, Eppig JT, et al. Gene Ontology: tool for the unification of biology. Nat Genet 2000; 25:2 5-29. PubMed http://dx.doi.org/10.1038/75556

24. Widdel F, Bak F. Gram-negative mesophilic sulfate reducing bacteria. In The Prokaryotes. Balows, A., Trüper, H.G., Dworkin, M., Harder, W., and Schleifer, K.H. 1992, New York: Springer, pp 3352-3378.

25. Marmur J. A procedure for the isolation of DNA from microorganisms. J Mol Biol 1961; 3:208218. http://dx.doi.org/10.1016/S00222836(61)80047-8

26. The SOAPdenovo software package. http://soap.genomics.org.cn/soapdenovo.html

27. Integ rated Microbial Genome portal of JGI. http://genomesonline.org/cgibin/GOLD/bin/GOLDCards.cgi?goldstamp=Gi229 06.

28. NCBI.

http://www.ncbi.nlm.nih.gov/genome?db=genom $\underline{\text { e\&cmd=Retrieve \&dopt=Overview } \& \text { list }+ \text { uids }=160}$ $\underline{9}$.

29. Delcher AL, Harmon D, Kasif S, White O, Salzberg SL. Improved microbial gene identification with GLIMMER. Nucleic Acids Res 1999; 27:4636-4641. PubMed http://dx.doi.org/10.1093/nar/27.23.4636

30. Lowe TM, Eddy SR. tRNAscanSE: a prog ram for improved detection of transfer RNA genes in genomic sequence. Nucleic Acids Res 1997;

25:955-964. PubMed http://dx.doi.org/10.1093/nar/25.5.0955

31. Lagesen K, Hallin P, Rodland EA, Staerfeldt HH, Rognes T, Ussery DW. RNAmmer: consistent and rapid annotation of ribosomal RNA genes. Nucleic Acids Res 2007; 35:3100-3108. PubMed http://dx.doi.org/10.1093/nar/gkm160

32. Griffiths-Jones S, Moxon S, Marshall M, Khanna A, Eddy SR, Bateman A. Rfam: annotating noncoding RNAs in complete genomes. Nucleic Acids Res 2005; 33:D121-D124. PubMed http://dx.doi.org/10.1093/nar/gki081

33. DeMoll-Decker H, Macy JM. The periplasmic nitrite reductase of Thauera selenatis may catalyze the reduction of selenite to elemental selenium. Arch Microbiol 1993; 160:241-247. 
34. Tomei FA, Barton LL, Lemanski CL, Zocco TG. Reduction of selenate and selenite to elemental selenium by Wolinella succ inogenes. Can J Microbiol 1992; 38:1328-1333.

http://dx.doi.org/10.1139/m92-219

35. Bao P, Huang H. HuZY, HäggblomMM, ZhuYG. Impact of temperature, $\mathrm{CO}_{2}$ fixation and nitrate reduction on selenium reduction, by a paddy soil Clostridium strain. J App/ Microbiol 2013;

114:703-712. PubMed

http://dx.doi.org/10.1111/jam.12084

36. Switzer Blum J, Burns Bindi A, Buzzelli J, Stolz JF, Oremland RS. Bacillus arsenic oselenatis, sp. nov., and Bacillus selenitireducens, sp. nov.: two haloalkaliphiles from Mono Lake, California that respire oxyanions of selenium and arsenic. Arch
Microbiol 1998; 171:19-30. PubMed

http://dx.doi.org/10.1007/s002030050673

37. Rauschenbach I, Yee N, Häggblom MM, Bini E. Energy metabolism and multiple respiratory pathways revealed by genome sequencing of Desulfurisp irillum indic um strain S5. Environ Microbiol 2011; 13:1611-1621. PubMed http://dx.doi.org/10.1111/j.14622920.2011.02473.x

38. Bini E, Rauschenbach I, Narasingarao $P$, Starovoytov V, Land M, Hauser L, Jeffries CD, Held B, Bruce D, Detter C, et al. Complete genome sequence of Desulfurispirillum indic um strain S5 ${ }^{\top}$. Stand Genomic Sci 2011; 5:371-378. PubMed http://dx.doi.org/10.4056/sigs.2425302 